\title{
Occurrence of plant-parasitic nematodes on enset (Ensete ventricosum) in Ethiopia with focus on Pratylenchus goodeyi as a key species of the crop
}

\author{
Selamawit A. KIDAne ${ }^{1,2}$, Beira H. Meress A ${ }^{3}$, Solveig HAUKELAND ${ }^{4,5}$, \\ Trine Hvoslef-Eide ${ }^{1, *}$, Christer MAgnusson ${ }^{4}$, Marjolein Couvreur ${ }^{6}$, Wim Bert ${ }^{6}$ and \\ Danny L. COYNE ${ }^{2,6}$ \\ ${ }^{1}$ Norwegian University of Environmental and Life Sciences, NMBU, P.O. Box 5003, 1432 Ås, Norway \\ ${ }^{2}$ International Institute of Tropical Agriculture, IITA, PMB 5320, Ibadan, Nigeria \\ ${ }^{3}$ Jimma University College of Agriculture and Veterinary Medicine, P.O. Box, Jimma, Ethiopia \\ ${ }^{4}$ The Norwegian Institute of Bioeconomy Research, NIBIO, P.O. Box 115, 1431 Ås, Norway \\ ${ }^{5}$ International Centre of Insect Physiology and Ecology, P.O. Box 30772-00100, Nairobi, Kenya \\ ${ }^{6}$ Nematology Research Unit, Department of Biology, Ghent University, Campus Ledeganck, Ledeganckstraat 35, B-9000 \\ Ghent, Belgium
}

Received: 24 July 2020; revised: 6 September 2020 Accepted for publication: 7 September 2020; available online: 20 October 2020

\begin{abstract}
Summary - Enset (Ensete ventricosum) is an important starch staple crop, cultivated primarily in south and southwestern Ethiopia. Enset is the main crop of a sustainable indigenous African system that ensures food security in a country that is food deficient. Related to the banana family, enset is similarly affected by plant-parasitic nematodes. Plant-parasitic nematodes impose a huge constraint on agriculture. The distribution, population density and incidence of plant-parasitic nematodes of enset was determined during August 2018. A total of 308 fields were sampled from major enset-growing zones of Ethiopia. Eleven plant-parasitic nematode taxa were identified, with Pratylenchus (lesion nematode) being the most prominent genus present with a prominence value of 1460. It was present in each sample, with a highest mean population density per growing zone of $16050(10 \mathrm{~g} \mathrm{root})^{-1}$, although densities as high as 25000 were observed in fields at higher altitudes in Guraghe (2200-3000 m a.s.l.). This lesion nematode is found in abundance in the cooler mountainous regions. Visible damage on the roots and corms was manifested as dark purple lesions. Using a combination of morphometric and molecular data, all populations were identified as $P$. goodeyi and similar to populations from Kenya, Uganda and Spain (Tenerife). Differences in population densities amongst cultivars indicate possible resistance of enset to $P$. goodeyi.
\end{abstract}

Keywords - altitude, food security, lesion nematode, molecular data, morphology, prominence value.

Ensete ventricosum, commonly known as enset, is a large perennial herbaceous plant belonging to the Musacea family, together with banana and plantain. Unlike banana and plantain, however, enset does not produce bunches but instead produces a large underground corm that is harvested. The pseudostem is formed from a bundle of leaf sheaths and large leaves, which may reach up to $10 \mathrm{~m}$ high and $2 \mathrm{~m}$ diam. (Westphal \& Stevels, 1975). Wild enset species are found distributed over sub-Saharan Africa and Asia, but in Ethiopia, where it has been domesticated, it is cultivated as an important food crop grown

*Corresponding author, e-mail: trine.hvoslef-eide@nmbu.no on approximately 400000 ha (CSA-Ethiopia, 2016). As a key starch staple food source, enset provides food security for over 20 million people, or at least $20 \%$ of the Ethiopian population. Furthermore, it is also used for animal feed, fibre, construction and medicine (Brandt et al., 1997). The crop grows best at cooler, higher altitudes and is found mostly between $1200-3100 \mathrm{~m}$ a.s.l., in the south and southwestern areas of the country. Enset-based farming systems represent a traditional and sustainable form of agriculture, which includes a diverse range of crops that are cultivated alongside enset (Cheesman, 1947; Sim- 
monds, 1962; Brandt et al., 1997). Enset is a perennial crop that takes, on average, 7 years to mature; however, as with most crops, the period to maturity is likely to be lengthened under challenge from biotic and abiotic threats. Identifying the biotic threats that challenge enset, and consequently addressing them, has received limited attention.

A number of constraints challenge enset production, with bacterial wilt disease caused by Xanthomonas vasicola pv. musacearum (Xvm) (previously named $X$. campestris pv. musacearum (Xcm)) (Studholme et al., 2020) receiving most attention (Addis et al., 2004, 2008; Nakato et al., 2018). The enset root mealy bug (Cataenococcus ensete) can cause severe damage to the roots and corm, reducing crop vigour and production (Addis et al., 2010). Also, fungal diseases such as a Sclerotium sp. root and corm rot, and Acremonium inflorescence spot, causing necrosis on flower bracts and leaves, can affect production, although they appear not to be widespread (Tesera \& Quimio, 1994; Quimio \& Tesera, 1996). A newly reported leaf streak disease, caused by a new Badnavirus species, has also recently been identified (Abraham et al., 2018; Abraham, 2019). Plant-parasitic nematodes, well known as major production constraints to banana and plantain production (Sikora et al., 2018), have received only limited attention on enset (Coyne \& Kidane, 2018; Coyne et al., 2018). A few studies have associated various nematode species with the crop, with the lesion nematode Pratylenchus goodeyi appearing to be the most prevalent (Peregrine \& Bridge, 1992; Tesera \& Quimio, 1994; Speijer \& Fogain, 1998; Mandefro \& Dagne, 2000; Swart et al., 2000; Bogale et al., 2004). The root-knot nematodes Meloidogyne incognita, M. javanica and M. ethiopica, and Aphelenchoides ensete have also been reported as potential production constraints (Mandefro \& Dagne, 2000; Swart et al., 2000).

Compared to other pathogens, nematodes are, in general, poorly recognised in sub-Saharan Africa (Coyne et al., 2018) and Ethiopia in particular (Abebe et al., 2015). Despite a handful of studies associating nematode species with enset, there has been no concerted effort to establish the pest potential of nematodes on enset. The current study serves to provide a basis for more focused studies towards understanding the pest potential of nematodes on the crop. A comprehensive sampling of nematodes was undertaken in southern Ethiopia to establish the current situation regarding nematode incidence across the region, in relation to commonly cultivated cultivars and the influence of altitude (temperature) on their occurrence, with emphasis on the most prevalent nematode genus, Pratylenchus. This study also served to identify 'hot spots' where material could be collected for use in trials.

\section{Materials and methods}

\section{SURVEY AREA}

Enset root and soil samples were collected from the southern part of Ethiopia, from administrative zones where enset is most commonly grown (Sidama, Hadiya, Kembata and Keffa) in August 2018. Based on the Ethiopian administrative structure a total of 308 fields were sampled; 72 fields were selected randomly from each of the four zones and an additional ten fields each from Guraghe and Jimma zones (Fig. 1). In some fields where multiple cultivars were present, samples were collected separately from different cultivars. For each sample, the location, geographical coordinates, altitude and enset cultivar were recorded. Enset thrives best in slightly acidic, well-drained and fertile soils (Brandt $e$ t al., 1997). Specific soil characteristics were not assessed for each site; however, we have observed that in each farm enset was grown in soils rich in organic matter. Root and soil samples were removed using a spade by excavating a hole $c a 0.5 \mathrm{~m}$ distance from the stem, from 3-4 plants of each cultivar per field and placed in plastic bags, labelled and stored in a cooler box for transport to the laboratory. Additional $P$. goodeyi populations were collected from Kenya and Uganda, and others supplied from Canary Islands (courtesy of Javier López-Cepero), which were included in the molecular assessment for comparison with Ethiopian populations.

\section{PROCESSING OF SAMPLES}

Soil and root samples were processed separately. Enset roots were carefully washed, cut longitudinally and chopped into ca $0.5 \mathrm{~mm}$-sized pieces and a $10 \mathrm{~g}$ subsample was used for nematode extraction. For soil samples, a $100 \mathrm{ml}$ sub-sample was extracted after fully mixing the soil for each sample. Nematodes were extracted from both soil and roots using a modified Baermann method over a period of $48 \mathrm{~h}$ (Hooper et al., 2005). Nematode suspensions were decanted and nematodes collected on a $38 \mu \mathrm{m}$ sieve, rinsed into beakers, reduced to $10 \mathrm{ml}$ and densities counted from $1 \mathrm{ml}$ aliquots under a compound microscope. Nematode densities were calculated for each root and soil sample and expressed as the number of ne- 


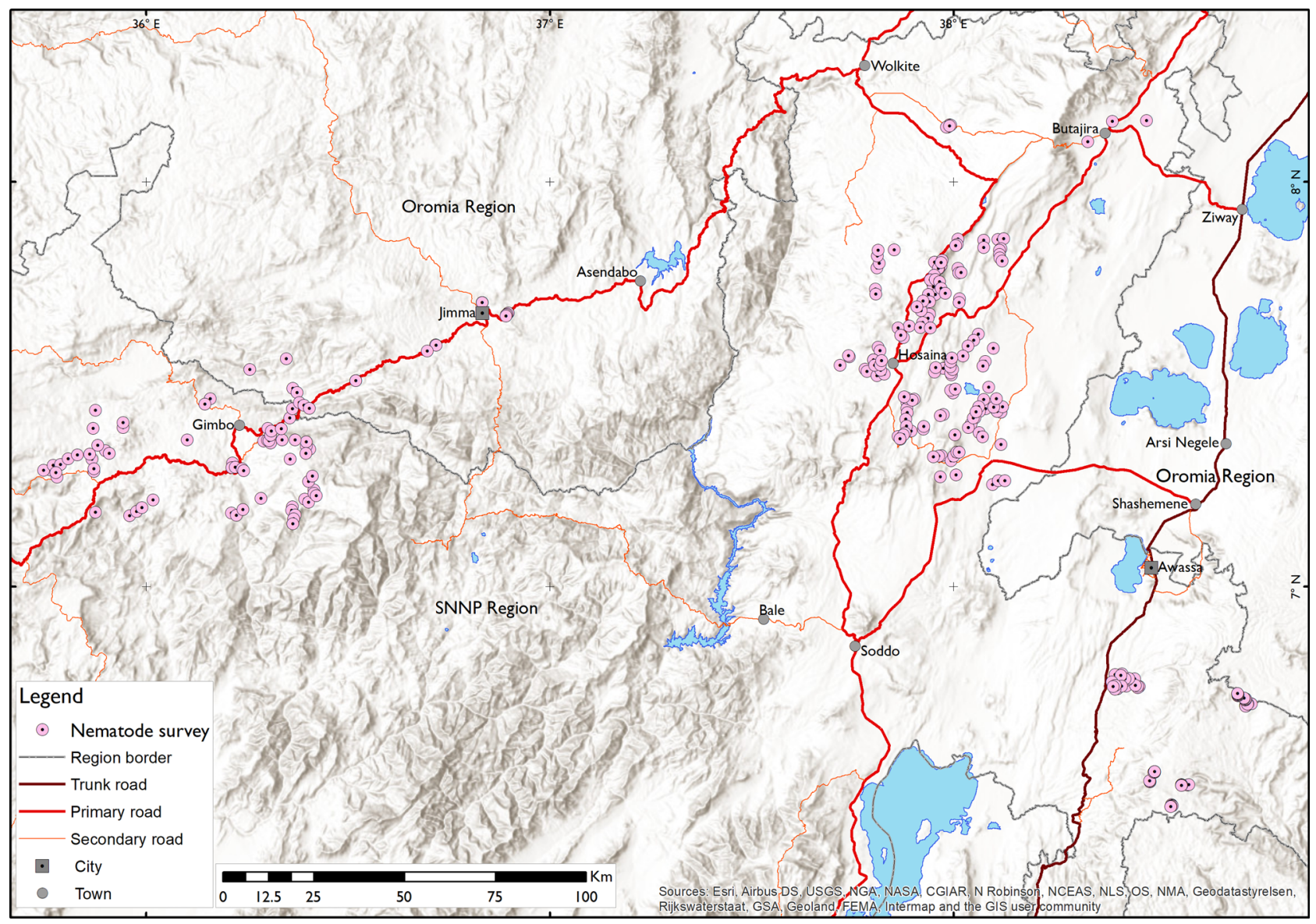

Fig. 1. Map showing nematode survey fields in southern Ethiopia.

matodes in $10 \mathrm{~g}$ root or $100 \mathrm{ml}$ soil. The extracted nematodes were subsequently heat-killed, with half the quantity preserved in triethanolamine formalin (TAF) to prepare permanent slides for morphological analyses and the remainder preserved in ethanol (97\%) for molecular analysis.

\section{MORPHOLOGICAL CHARACTERISATION}

Nematodes fixed in TAF were processed to anhydrous glycerin for permanent slides, following a modified glycerin-ethanol method (De Grisse, 1969). Morphological features were observed and measurements made using a Leica DM 6000 B compound microscope equipped with Leica Application Suite (LAS) version 4.6.1 fitted with an Andor iXon 885 EMCCD camera. Pratylenchus specimens were identified to species level based on available keys (Sher \& Allen, 1953; Castillo \& Vovlas, 2007).

\section{MOLECULAR CHARACTERISATION}

The ethanol-preserved nematodes were washed three times in $400 \mu \mathrm{l}$ of sterile water for $10 \mathrm{~min}$. DNA extraction was done by cutting an individual specimen and transferring the two pieces to an Eppendorf tube containing $20 \mu \mathrm{l}$ of WLB $(50 \mathrm{mM} \mathrm{KCl} ; 10 \mathrm{mM}$ Tris $\mathrm{pH} 8.3$; $2.5 \mathrm{mM} \mathrm{MgCl} 2 ; 0.45 \%$ NP-40 (Merck Life Sciences); $0.45 \%$ Tween-20). The samples were frozen for at least $10 \mathrm{~min} ; 1 \mu \mathrm{l}$ proteinase $\mathrm{K}\left(1.2 \mathrm{mg} \mathrm{ml}^{-1}\right)$ was added and the samples were incubated for $1 \mathrm{~h}$ at $65^{\circ} \mathrm{C}$ and $10 \mathrm{~min}$ at $95^{\circ} \mathrm{C}$. Finally, the samples were centrifuged for $1 \mathrm{~min}$ at max speed $20(800 \mathrm{~g})$. They were stored at $-20^{\circ} \mathrm{C}$ before running the PCR. The supernatant was taken as a template for PCR reaction; $2 \mu \mathrm{l}$ was transferred to an Eppendorf tube containing $25 \mu \mathrm{l}$ master mix (Derycke et al., 2010) and PCR amplification was performed using a Bio-Rad T100 ${ }^{\mathrm{TM}}$ thermocycler. For the D2-D3 expansion segment of the large sub-unit (LSU) rDNA primers MalF 
(5'-GGATAGAGCCRACGTATCTG-3') (Wiśniewska \& Kowalewska, 2015) and 1006R (5'-GTTCGATTAGTCTT TCGCCCCT-3') (Holterman et al., 2008) were used. The PCR amplification conditions were: initial denaturation of $5 \mathrm{~min}$ at $94^{\circ} \mathrm{C}, 35$ cycles of $\left(94^{\circ} \mathrm{C}\right.$ for $1 \mathrm{~min} ; 52^{\circ} \mathrm{C}$ for $90 \mathrm{~s} ; 68^{\circ} \mathrm{C}$ for $2 \mathrm{~min}$ ), and a final extension of $10 \mathrm{~min}$ at $68^{\circ} \mathrm{C}$. The cytochrome $\mathrm{c}$ oxidase subunit 1 (COI) gene fragment was amplified using the forward primer JB3 (5'-TTTTTTGGGCATCCTGAAGTCTAT-3') (Derycke et al., 2010) and the reverse primer JB4prat (5'-CCTATTCTTAAAACATAATGAAAATG-3') adapted from Bowles et al. (1992) with an initial denaturation of $5 \mathrm{~min}$ at $94^{\circ} \mathrm{C}, 40$ cycles of $\left(94^{\circ} \mathrm{C}\right.$ for $1 \mathrm{~min} ; 48^{\circ} \mathrm{C}$ for $30 \mathrm{~s} ; 72^{\circ} \mathrm{C}$ for $100 \mathrm{~s}$ ), and a final extension of $10 \mathrm{~min}$ at $72^{\circ} \mathrm{C}$. The PCR products were separated by electrophoresis on agarose gel stained with GelRed (Biotium) and visualised under UV light. Sanger sequencing of purified PCR fragments was carried out in forward and reverse direction by Macrogen (Europe). Contigs were assembled using Geneious 2019.0.4 (Biomatters; http://www. geneious.com). All contigs were subjected to BLAST searches to check for possible contaminations. The resulting sequences were analysed with other relevant sequences available in GenBank. Multiple alignments of the different DNA sequences were made using MUSCLE with default parameters and followed by manual trimming of the poorly aligned ends using Geneious 2019.0.4. Phylogenetic trees were created by using MrBayes 3.2.6 addin of Geneious with the GTR + I + G model. The Markov chains for generating phylogenetic trees were set at $1 \times$ $10^{6}$ generations, four runs, $20 \%$ burn-in and sub-sampling frequency of 500 generations (Huelsenbeck \& Ronquist, 2001).

\section{STATISTICAL TREATMENT OF DATA}

Nematode population densities were calculated for each genus and/or species per field. Nematode count data were $\log (x+1)$ transformed before analysis to minimise variation and conform data to normal distribution (Zuur et al., 2010). The percentage frequency of occurrence was calculated as $(\mathrm{FO}=$ (number of sites where a genus was detected/total number of sites) $\times 100$ ), and prominence values $(\mathrm{PV}=$ population density $\times$ frequency of occurrence/10) (De Waele \& Jordaan, 1988) were also calculated for each nematode genus and/or species (identified from both soil and root samples) across the sampled fields. PV is an indication of the relationship of population density and frequency. The association between ne- matode density and enset cultivar and the association between nematode density and altitude was analysed using RStudio ${ }^{\circledR}$ and Pearson's correlation analysis. Using the GIS coordinates for each farm sampled, distribution maps were created for the key nematode species $P$. goodeyi.

\section{Results}

A total of 308 enset field samples were collected from six administrative zones. Eleven plant-parasitic nematode genera were identified: Pratylenchus, Meloidogyne, Helicotylenchus, Scutellonema, Tylenchorhynchus, Rotylenchulus, Aphelenchoides, Cephalenchus, Pratylenchoides, Trophurus and Hoplolaimus (Table 1). The genera Pratylenchus, Meloidogyne and Aphelenchoides were recovered from roots (Table 2). With regard to frequency of occurrence (FO\%), Pratylenchus and Helicotylenchus species were present in 100 and $52 \%$ of the soil samples, respectively, followed by Tylenchorhynchus (16\%), Scutellonema (10\%) and Meloidogyne (13\%). Pratylenchus, Meloidogyne and Aphelenchoides species occurred in 100, 8 and $4 \%$ of root samples, respectively (Table 2). Pratylenchus was the most prominent nematode taxa across the enset-growing areas with a prominence value of 1460, followed by Meloidogyne and Aphelenchoides with PVs of 20 and 4, respectively. Pratylenchus spp. densities were highest in the highlands of Guraghe, where mean densities of 16050 and $12217(10 \mathrm{~g}$ root $)^{-1}$ were observed in Meskan and Ezha woredas/districts, respectively, although densities as high as 25000 $(10 \mathrm{~g} \text { root })^{-1}$ were recorded from individual fields. The elevation of these areas ranged between 2200 and $3000 \mathrm{~m}$ a.s.l. (Fig. 2). Roots from these locations appeared dry and, when split longitudinally, extensive black or purple necrotic cortical tissue was evident (Fig. 3A), which was also observed on the corms (Fig. 3B). Roots from locations infected with Meloidogyne presented visible galling damage (Fig. 3C) but no obvious damage was associated with Aphelenchoides species.

This study found $P$. goodeyi to be present in every farm sampled and thus widely distributed, but alongside a range of species associated with enset and the cooler climate at the highest altitudes ( $>2200 \mathrm{~m}$ a.s.l.). There was a positive correlation $(r=0.11, P=0.08)$ between altitude and population densities of $P$. goodeyi (Fig. 4). The correlation of $P$. goodeyi root density with cultivar showed that densities varied from 20 ('Bedo') to 4600 ('Birdo') $(10 \mathrm{~g} \text { root })^{-1}$, but no statistically significant differences in 


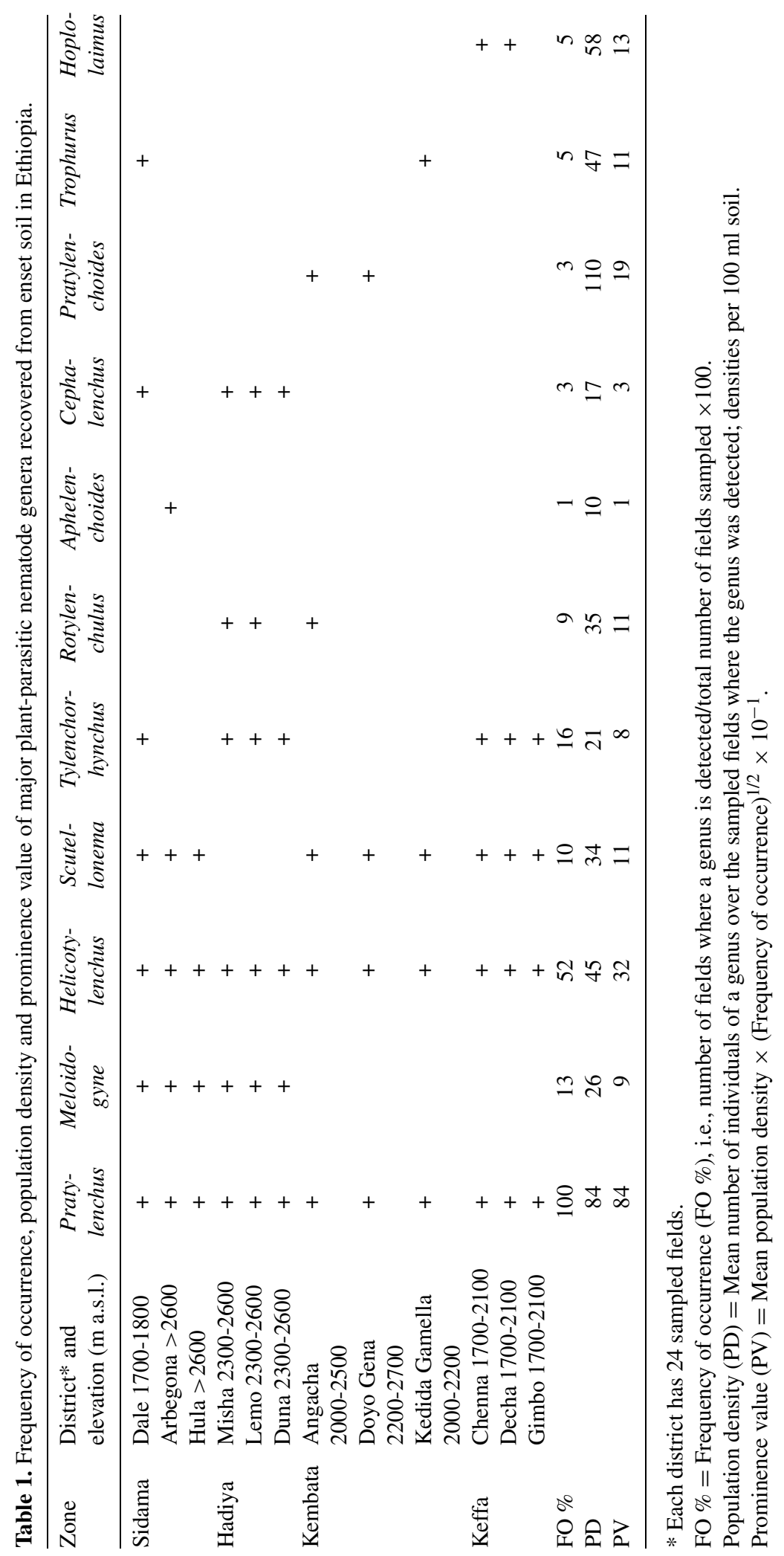


Table 2. Frequency of occurrence, population density and prominence value of major plant-parasitic nematode taxa recovered from enset roots in Ethiopia.

\begin{tabular}{|c|c|c|c|c|}
\hline Zone & District* and elevation (m a.s.l.) & Pratylenchus & Meloidogyne & Aphelenchoides \\
\hline \multirow[t]{3}{*}{ Sidama } & Dale 1700-1800 & + & + & \\
\hline & Arbegona $>2600$ & + & + & \\
\hline & Hula $>2600$ & + & + & \\
\hline \multirow[t]{3}{*}{ Hadiya } & Misha 2300-2600 & + & + & + \\
\hline & Lemo 2300-2600 & + & + & \\
\hline & Duna 2300-2600 & + & + & \\
\hline \multirow[t]{3}{*}{ Kembata } & Angacha $2000-2500$ & + & & + \\
\hline & Doyo Gena 2200-2700 & + & & + \\
\hline & Kedida Gamella 2000-2200 & + & & \\
\hline \multirow[t]{3}{*}{ Keffa } & Chenna 1700-2100 & + & & \\
\hline & Decha 1700-2100 & + & & \\
\hline & Gimbo 1700-2100 & + & & \\
\hline $\mathrm{FO}(\%)$ & & 100 & 8 & 4 \\
\hline $\mathrm{PD}$ & & 1460 & 69 & 22 \\
\hline PV & & 1460 & 20 & 4 \\
\hline
\end{tabular}

* Each district has 24 sampled fields.

FO $\%=$ Frequency of occurrence (FO \%), i.e., number of fields where a genus is detected/total number of fields sampled $\times 100$.

Population density $(\mathrm{PD})=$ Mean number of individuals of a genus over the sampled fields where the genus was detected; densities per $100 \mathrm{ml}$ soil.

Prominence value $(\mathrm{PV})=$ Mean population density $\times(\text { Frequency of occurrence })^{1 / 2} \times 10^{-1}$.

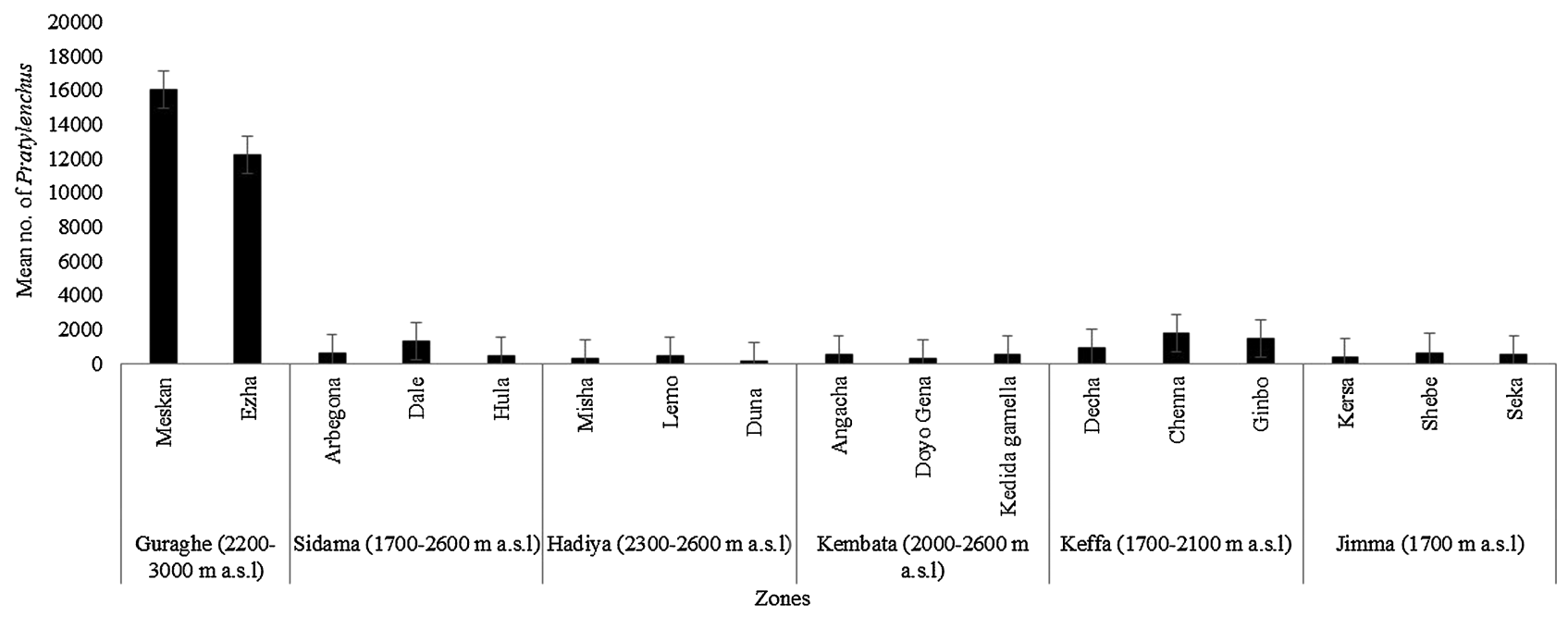

Fig. 2. Pratylenchus goodeyi densities per $10 \mathrm{~g}$ root across enset-growing zones of Ethiopia.

densities amongst the cultivars were observed. The number of samples for each cultivar also differed, reflecting farmer and/or geographical preferences for different cultivars.
Pratylenchus was the most frequently occurring nematode genera in soil samples with mean soil density of 84 nematodes $(100 \mathrm{ml} \mathrm{soil})^{-1}$ followed by Helicotylenchus (45) and Scutellonema (34). The genera Pratylen- 


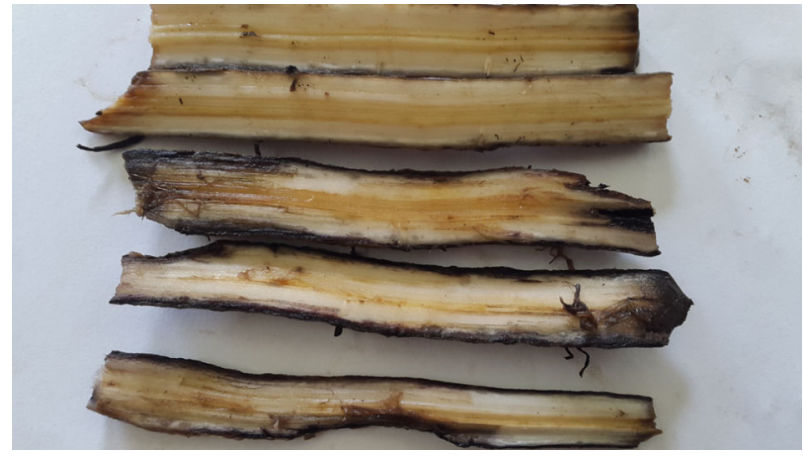

A

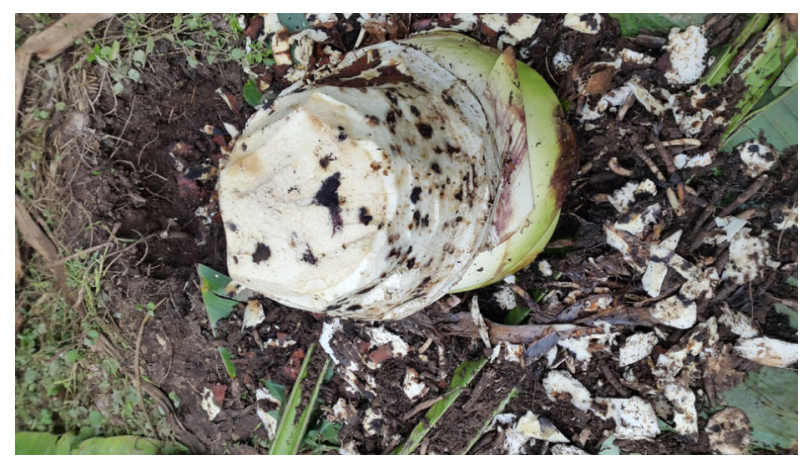

B

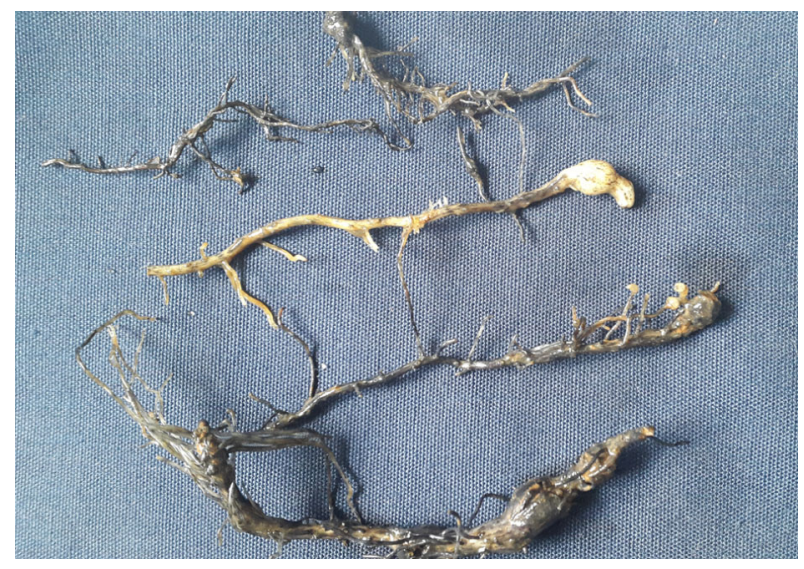

$\mathrm{C}$

Fig. 3. A: Longitudinal section of enset roots showing lesions caused by the lesion nematode; B: Purple lesions caused by the lesion nematode on enset corm; C: Galling on enset roots caused by root-knot nematodes, Meloidogyne spp.

choides, Hoplolaimus and Trophurus, which occurred in fewer sites, had densities of 110, 58 and 47 nematodes $(100 \mathrm{ml} \mathrm{soil})^{-1}$ (Table 1).

\section{MORPHOLOGICAL AND MOLECULAR CHARACTERISATION OF PRATYLENCHUS}

Using a combination of morphometric and molecular data with Pratylenchus specimens, $P$. goodeyi was the only species of the genus identified. Morphologically, the Ethiopian populations displayed typical diagnostic characteristics of $P$. goodeyi, including four lip annuli, four inconspicuous lateral field lines, stylet 16-18 $\mu \mathrm{m}$ long with pronounced, anteriorly flattened stylet knobs, large spermatheca filled with sperm, tail conoid, ventrally concave with dorsal contour sinuate just prior to tail tip, which matched the characterisation described by Castillo \& Vovlas (2007). Seven Pratylenchus specimens (five females and two males) were measured: female; $\mathrm{L}=$ $0.56 \mathrm{~mm} ; \mathrm{a}=32.88 ; \mathrm{b}=4.12 ; \mathrm{c}=17.93 ; \mathrm{V}=73.42$; stylet $=16.44 \mu \mathrm{m} ;$ male: $\mathrm{L}=0.55 \mathrm{~mm} ; \mathrm{a}=29.48 ; \mathrm{b}=$ $4.36 ; \mathrm{c}=23.1 ; \mathrm{T}=55.52$; stylet $=16.1 \mu \mathrm{m}$.

Pratylenchus goodeyi populations from Ethiopia, Kenya, Uganda and the Canary Islands were used for molecular analysis. Eighty-one D2-D3 of 28S rDNA (GenBank accession numbers of selected sequences: MT569985, MT569991-94) and 101 mtDNA COI sequences with a maximum intraspecific variability of, respectively, $3(0.5 \%)$ and $16(4.1 \%)$ nucleotides were obtained. The D2-D3 phylogenetic tree (based on $652 \mathrm{bp}$ long alignment with 116 sequences) revealed that all obtained sequences are in a maximally supported clade together with virtually identical $P$. goodeyi sequences from GenBank (0-3 bp difference), but without internal resolution (Fig. 5). For COI, sequences were obtained with premature stop codons that appeared difficult to align with other Pratylenchus COI sequences. This indicates that the used primers appeared not to have targeted the genuine $\mathrm{COI}$ region, but mitochondrial fragments into the nuclear genome (nuclear mitochondrial pseudogenes). Subsequent attempts with several other primers (Folmer et al., 1994; Kanzaki \& Futai, 2002; Derycke et al., 2010) did not alleviate this pseudogene problem, i.e., always the same pseudogene was obtained. Nevertheless, the resulting phylogenetic tree (based on $360 \mathrm{bp}$ long alignment with 102 sequences) clearly clustered all our sequences with a very similar (0-16 bp different) $\mathrm{COI}$ reference of $P$. goodeyi (unpublished sequence in the framework of the study of Janssen et al. (2017a)), which confirms the species identity. However, the internal resolution in this $P$. goodeyi clade was limited and without relation to host or location, impeding statements related to intraspecific relations (separated analyses of the pseudogene sequences). Despite the evidence of nuclear pseudogenes that com- 


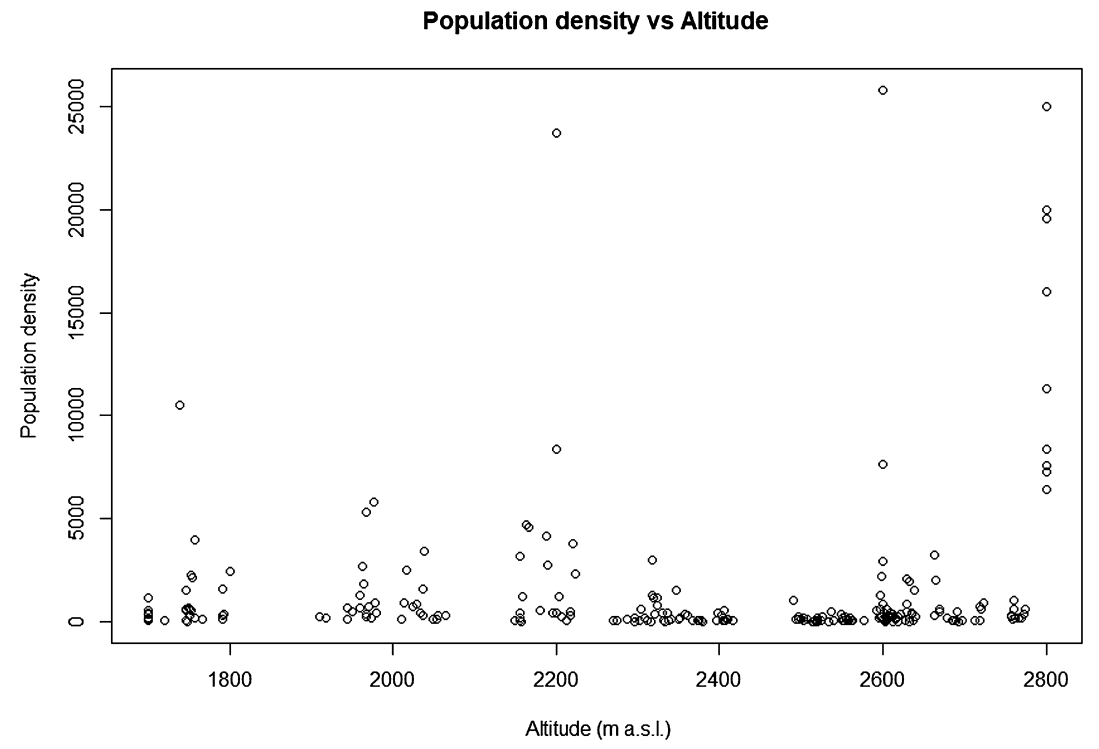

Fig. 4. Correlation between altitude and Pratylenchus goodeyi density on enset roots in Ethiopia.

plicated this study, it was evident that all investigated Pratylenchus species are unmistakably $P$. goodeyi, which is confirmed by morphology, D2-D3 sequences and a putative species-specific pseudogene (Fig. 5).

\section{Discussion}

The present study shows that although a range of plantparasitic nematode species are associated with enset in the major producing zones in south and south western Ethiopia, $P$. goodeyi dominates strongly and is the most prominent species. Our study also represents the most extensive assessment of nematodes on enset to date, and the latest since Addis et al. (2006) with 98 farms sampled in 2004 and Bogale et al. (2004) who assessed 49 farms in 1999. The predominance of $P$. goodeyi in the previous studies and in our study identifies this nematode as probably the greatest nematode threat to enset. Root-knot nematodes (Meloidogyne spp.) were recovered from a few root samples, with relatively lower PV scores and densities; galling damage was observed on enset roots in the current study, which indicates it is becoming more problematic as this is the first time this appears to have been observed. Previously Meloidogyne spp. was found in $9 \%$ of 98 enset samples (Addis et al., 2006) and 60\% in a smaller study (Bogale et al., 2004), which shows some variability in the recovery of these nematodes between studies. The current comprehensive study therefore demonstrates the incidence of Meloidogyne spp. associated with the crop across the region and supports the growing concern of this pest becoming more serious on crops across sub-Saharan Africa (Coyne et al., 2018). Aphelenchoides spp. were isolated from the roots of enset, reflecting previous studies, although no discoloured leaves were observed, which has previously been associated with $A$. ensete infection (Swart et al., 2000; Bogale et al., 2004; Addis et al., 2006). Although Aphelenchoides spp. have been associated with damage to enset, this does not appear to be prominent $(\mathrm{PV}=4)$. No Helicotylenchus multicinctus were recorded from the roots, even though this nematode is common on banana in Ethiopia and was recorded from 5\% of enset roots by Addis et al. (2006). Neither was any Radopholus similis recorded on enset, in line with previous studies (Bogale et al., 2004; Addis et al., 2006), even though it was present on banana in the previous studies (Addis et al., 2006). Enset therefore, may not be a suitable host for $H$. multicinctus or $R$. similis, unlike banana. However, environmental factors may not be suitable for $R$. similis, which is known to be thermophilic and present at warmer, lower altitudes than enset is generally cultivated (Kashaija et al., 1994).

In line with previous studies (Bogale et al., 2004; Addis et al., 2006), Meloidogyne, Helicotylenchus, Scutellonema, Tylenchorhynchus and Rotylenchulus were among the plant-parasitic nematodes associated with enset soil samples. Our study also detected species of Cephalenchus, Pratylenchoides, Trophurus and Hoplo- 

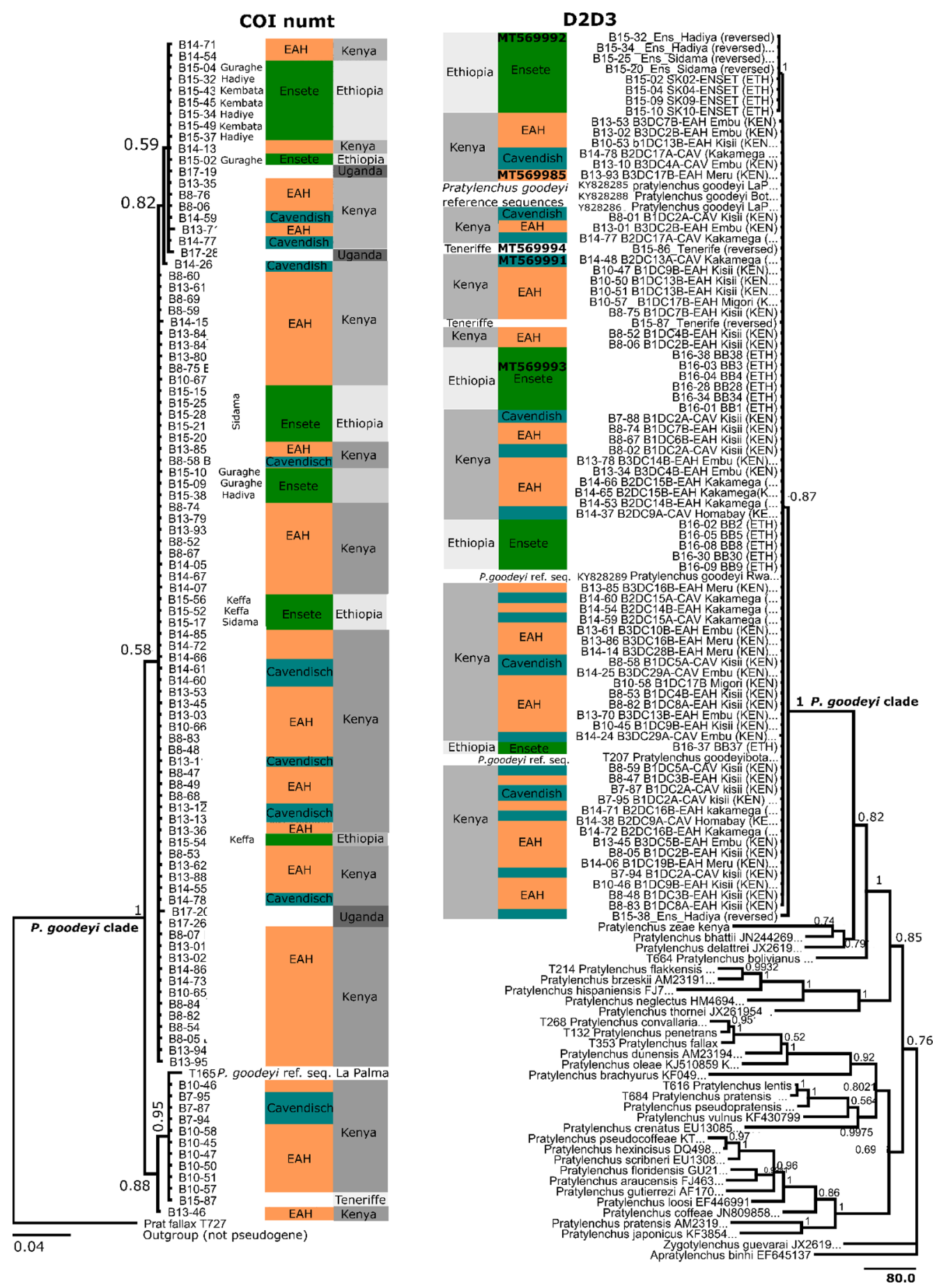

Fig. 5. Bayesian 50\% majority-rule consensus tree inferred from Pratylenchus goodeyi COI and D2-D3 (pseudogene) sequences, obtained from enset in southern Ethiopia, and from banana in Kenya and Tenerife. 
laimus from enset soil samples, but all were in relatively low densities and do not appear to be causing any major threat to the crop.

The incidence and distribution of $P$. goodeyi was prominent in higher altitudes (2000-3000 $\mathrm{m}$ a.s.1.), such as the extremely high densities observed in some farms from the

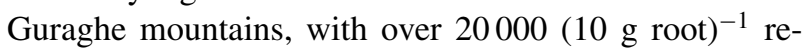
corded and even up to $26000(10 \mathrm{~g} \text { root })^{-1}$. This by far exceeds the density of $P$. goodeyi (5484 $\left.(10 \mathrm{~g} \text { root })^{-1}\right)$ previously recorded by Bogale et al. (2004) from enset rhizome tissue and the 15000 recorded by Peregrine \& Bridge (1992). A maximum of 5600 nematodes $(10 \mathrm{~g} \text { root })^{-1}$ was recovered from banana in Cameroon (Bridge et al., 1995) and mean densities of 2500 nematodes from East African Highland banana roots in Uganda (Kashaija et al., 1994). Enset, therefore, appears to be able to tolerate high densities of $P$. goodeyi. There are no reports on how this affects crop growth and production; therefore, it remains speculative as to the level of damage being caused to enset. A case study on banana in Rwanda showed that the highest $P$. goodeyi densities and root necrosis were present in the best performing banana plants, a possible explanation being that the negative impact of the nematode was masked by the fact that the plants were receiving better nutrient inputs (Gaidashova et al., 2009). However, it is assumed that at such high densities as observed during our study, substantial damage is being caused. Roots with high $P$. goodeyi densities were associated with root necrosis and purple lesions, while the outer cortex of corms at times presented severe necrotic lesioning, especially on planting materials (Fig. 3b). When visiting farms, substantial portions of the corm with lesions and rotten areas were observed being removed during the preparation of corm material for food processing, resulting in much reduced corm size and food quantity. The wide range in $P$. goodeyi densities could indicate possible variations in the biology or pathogenicity of geographic populations. Populations of $P$. goodeyi from elsewhere within Africa were also shown to be similar to the Ethiopian populations, indicating a relatively recent distribution of the species within Africa (Bridge et al., 1997). Difference in pathogenicity between geographic populations or 'pathotypes' has been speculated, given the contradictory evidence of damage observed by $P$. goodeyi on bananas and the uniformity of P. goodeyi populations (Speijer \& Bosch, 1996; Coyne, 2007). Populations occurring in Tanzania appeared similar to those from other countries (Mgonja et al., 2019), even though some of these populations were recovered from tropical lowland areas, which is atypical for the species. Similarly, populations of $P$. goodeyi are being recovered from other tropical lowland locations (Coyne, 2007; Sikora et al., 2018). As yet, there is no conclusive evidence to demonstrate differences between populations.

In the current study, both morphometric and molecular techniques were used to identify the Pratylenchus populations. In general, morphological identification of Pratylenchus species is difficult due to the low number of diagnostic features, high morphological plasticity and incomplete taxonomic descriptions (Castillo \& Vovlas, 2007; Janssen et al., 2017a). DNA-based identification tools are therefore important for Pratylenchus species (Waeyenberge et al., 2000), but also a strong link between morphology and DNA sequences is of crucial importance to prevent sequence-based misidentifications (Janssen et al., 2017b). However, the morphological characterisation of the Ethiopian P. goodeyi all corresponded closely to the documented characteristics (Sher \& Allen, 1953). Pratylenchus goodeyi is also one of the few Pratylenchus species that can be relatively easily identified based on morphology alone. The molecular assessment of P. goodeyi populations, based on the D2-D3 and $C O I$ region, and including specimens from countries other than Ethiopia, did not reveal informative differences. As expected, intraspecific resolution of the D2-D3 region is limited for Pratylenchus (Janssen et al., 2017a). For COI a higher resolution can be expected; however, sequences that are most likely nuclear pseudogenes have complicated our analyses. Pseudogenes have been detected in several eukaryotes and impede the usefulness and dependability of DNA (Leite, 2012). Nonetheless, for nematode taxonomic and phylogenetic studies, pseudogenes are not well recognised as being problematic. Furthermore, the $C O I$ region of several Pratylenchus has been sequenced (Janssen et al., 2017a, b), but the pseudogene problem only appears to be present in $P$. goodeyi, in all globally distributed populations. How specifically $P$. goodeyi differs in this respect remains to be investigated.

Although there was no significant difference in $P$. goodeyi population densities among the cultivars, variations in levels of infection across cultivars from the current study show that possible differences in resistance exist in enset against $P$. goodeyi. The assessment of 111 cultivars using Random Amplified Polymorphic DNA (RAPD), demonstrated that each cultivar had unique DNA (Birmeta et al., 2002). However, given the difference in infection levels between geographic and altitudinal locations, this needs proper assessment through controlled inoculation studies. Differences in nematode densities between 71 en- 
set cultivars, sampled from 98 farms, showed possible differences in resistance to $P$. goodeyi (Bogale et al., 2004) but this again requires verification.

During our survey, we perceived that very few farmers were aware of, or had any knowledge of, nematode pests. To some extent, they were aware of the bacterial wilt problem on enset and other foliar diseases but not of nematodes. As in the case of many smallholder farmers and agricultural agents even in sub-Saharan Africa, there remains a huge gap in the awareness of nematodes as pests and their management, even though nematodes are regarded as economically important pests of most crops in the region (Coyne et al., 2018). With such a high frequency of occurrence of $P$. goodeyi on enset in Ethiopia, and with such high densities recorded, it is assumed that this nematode is causing damage to crop growth and production. With a lack of information on the damage potential of this nematode to enset, this survey will provide a basis for identifying hotspots for nematode material for use in assessing the efficacy of the nematode on enset, potential on-farm assessment and interaction of nematodes with other organisms.

\section{Acknowledgements}

The authors thank the Norwegian Agency for Development Cooperation (Norad) for funding this study which is part of the project "Controlling disease in sweet potato and enset in South Sudan and Ethiopia to improve productivity and livelihoods under changing climatic conditions using modern technologies" under the NORHED program (Agreement No. ETH-13/0017).

\section{References}

Abebe, E., Mekete, T., Seid, A., Meressa, B.H., Wondafrash, M., Addis, T., Getaneh, G. \& Abate, B.A. (2015). Research on plant-parasitic and entomopathogenic nematodes in Ethiopia: a review of current state and future direction. Nematology 17 , 741-759. DOI: 10.1163/15685411-00002919

Abraham, A. (2019). Emerged plant virus disease in Ethiopian agriculture: causes and control options. Ethiopian Journal of Agricultural Sciences 29, 39-55.

Abraham, A., Winter, S., Richert-Pöggeler, K.R. \& Menzel, W. (2018). Molecular characterization of a new badnavirus associated with streak symptoms on enset (Ensete ventricosum, Musaceae). Journal of Phytopathology 166, 565-571. DOI: 10.1111/jph.12719
Addis, T., Handoro, F. \& Blomme, G. (2004). Bacterial wilt (Xanthomonas campestris pv. musacearum) on enset and banana in Ethiopia. InfoMusa 13, 44-45.

Addis, T., Blomme, G., Turyagyenda, L., Van den Berg, E. \& De Waele, D. (2006). Nematodes associated with enset and banana in the highlands of Ethiopia. International Journal of Nematology 16, 118-125.

Addis, T., Turyagyenda, L.F., Alemu, T., Karamura, E. \& Blomme, G. (2008). Garden tool transmission of Xanthomonas campestris pv. musacearum on banana (Musa spp.) and enset in Ethiopia. In: IV international symposium on banana: international conference on banana and plantain in Africa: harnessing international partnerships to increase research impact 879, pp. 367-372. DOI: 10.17660/ActaHortic. 2010.879.39

Addis, T., Azerefegne, F., Alemu, T., Lemawork, S., Tadesse, E., Gemu, M. \& Blomme, G. (2010). Biology, geographical distribution, prevention and control of the enset root mealybug, Cataenococcus ensete (Homoptera: Pseudococcidae) in Ethiopia. Tree and Forestry Science and Biotechnology 4, 39-46.

Birmeta, G., Nybom, H. \& Bekele, E. (2002). RAPD analysis of genetic diversity among clones of the Ethiopian crop plant Ensete ventricosum. Euphytica 124, 315-325.

Bogale, M., Speijer, P., Mekete, T., Mandefro, W., Tessera, M. \& Gold, C. (2004). Survey of plant parasitic nematodes and banana weevil on Ensete ventricosum in Ethiopia. Nematologia Mediterranea 32, 223-227.

Bowles, J., Blair, D. \& McManus, D.P. (1992). Genetic variants within the genus Echinococcus identified by mitochondrial DNA sequencing. Molecular and Biochemical Parasitology 54, 165-173. DOI: 10.1016/0166-6851(92)90109-W

Brandt, S., Spring, A., Hiebsch, C., McCabe, J., Tabogie, E., Diro, M., Wolde-Michael, G., Yntiso, G., Shigeta, M. \& Tesfaye, S. (1997). The "tree against hunger": enset-based agricultural systems in Ethiopia. Washington, DC, USA, American Association for the Advancement of Science.

Bridge, J., Price, N.S. \& Kofi, P. (1995). Plant parasitic nematodes of plantain and other crops in Cameroon, West Africa. Fundamental and Applied Nematology 18, 251-260.

Bridge, J., Fogain, R. \& Speijer, P. (1997). The root lesion nematodes of banana. Pratylenchus coffeae (Zimmermann, 1898) Filip. \& Schu. Stek., 1941, Pratylenchus goodeyi Sher \& Allen, 1953. Musa Pest Fact Sheet 12. Montpellier, France, CGIAR.

Castillo, P. \& Vovlas, N. (2007). Pratylenchus (Nematoda: Pratylenchidae): diagnosis, biology, pathogenicity and management. Nematology Monographs and Perspectives 6 (Series Editors: Hunt, D.J. \& Perry, R.N.). Leiden, The Netherlands, Brill.

Cheesman, E. (1947). Classification of the bananas: the genus Ensete Horan. Kew Bulletin 2, 97-106. DOI: 10.2307/ 4109206 
Coyne, D. (2007). Pre-empting plant-parasitic nematode losses on banana in Africa: which species do we target? In: III international symposium on banana: ISHS-proMusa symposium on recent advances in banana crop protection for sustainable production and improved livelihoods. ISHS 828, pp. 227-236. DOI: $10.17660 /$ ActaHortic.2009.828.23

Coyne, D. \& Kidane, S. (2018). Nematode pathogens. In: Jones, D.R. (Ed.). Handbook of diseases of banana, abaca and enset. Wallingford, UK, CAB International, pp. 429-461.

Coyne, D.L., Cortada, L., Dalzell, J.J., Claudius-Cole, A.O., Haukeland, S., Luambano, N. \& Talwana, H. (2018). Plantparasitic nematodes and food security in sub-Saharan Africa. Annual Review of Phytopathology 56, 381-403. DOI: 10. 1146/annurev-phyto-080417-045833

CSA-Ethiopia (2016). Report on area and production of major crops. Statistical bulletin 586. Addis Ababa, Ethiopia, Central Statistical Agency.

De Grisse, A.T. (1969). Redescription ou modification de quelques techniques utilisées dans l'étude des nématodes phytoparasitaires. Mededelingen Rijksfaculteit der Landbouwwetenschappen Gent 34, 351-369.

De Waele, D. \& Jordaan, E.M. (1988). Plant-parasitic nematodes on field crops in South Africa. 1. Maize. Revue de Nématologie 11, 65-74.

Derycke, S., Vanaverbeke, J., Rigaux, A., Backeljau, T. \& Moens, T. (2010). Exploring the use of cytochrome oxidase c subunit 1 (COI) for DNA barcoding of free-living marine nematodes. PLoS ONE 5, e13716. DOI: 10.1371/journal. pone. 0013716

Folmer, O., Hoeh, W., Black, M. \& Vrijenhoek, R. (1994). Conserved primers for PCR amplification of mitochondrial DNA from different invertebrate phyla. Molecular Marine Biology and Biotechnology 3, 294-299.

Gaidashova, S., van Asten, P., De Waele, D. \& Delvaux, B. (2009). Relationship between soil properties, crop management, plant growth and vigour, nematode occurrence and root damage in East African Highland banana-cropping systems: a case study in Rwanda. Nematology 11, 883-894. DOI: 10. 1163/156854109X430310

Holterman, M., Rybarczyk, K., van den Elsen, S., Van Megen, H., Mooijman, P., Peña- Santiago, R., Bongers, T., Bakker, J. \& Helder, J. (2008). A ribosomal DNA-based framework for the detection and quantification of stress-sensitive nematode families in terrestrial habitats. Molecular Ecology Resources 8, 23-34. DOI: 10.1111/j.1471-8286.2007.01963.x

Hooper, D.J., Hallmann, J. \& Subbotin, S.A. (2005). Methods for extraction and processing. In: Luc, M., Sikora, R.A. \& Bridge, J. (Eds). Plant parasitic nematodes in subtropical and tropical agriculture, 2nd edition. Wallingford, UK, CAB International, pp. 53-84.

Huelsenbeck, J.P. \& Ronquist, F. (2001). MRBAYES: Bayesian inference of phylogenetic trees. Bioinformatics 17, 754-755. DOI: 10.1093/bioinformatics/17.8.754
Janssen, T., Karssen, G., Orlando, V., Subbotin, S.A. \& Bert, W. (2017a). Molecular characterization and species delimiting of plant-parasitic nematodes of the genus Pratylenchus from the penetrans group (Nematoda: Pratylenchidae). Molecular Phylogenetics and Evolution 117, 30-48. DOI: 10.1016/j. ympev.2017.07.027

Janssen, T., Karssen, G., Couvreur, M., Waeyenberge, L. \& Bert, W. (2017b). The pitfalls of molecular species identification: a case study within the genus Pratylenchus (Nematoda: Pratylenchidae). Nematology 19, 1179-1199. DOI: 10.1163/ 15685411-00003117

Kanzaki, N. \& Futai, K. (2002). A PCR primer set for determination of phylogenetic relationships of Bursaphelenchus species within the xylophilus group. Nematology 4, 35-41. DOI: 10. 1163/156854102760082186

Kashaija, I., Speijer, P., Gold, C. \& Gowen, S.R. (1994). Occurrence, distribution and abundance of plant parasitic nematodes of bananas in Uganda. African Crop Science Journal 2, 99-104. DOI: 20.500.12478/4578

Leite, L.A.R. (2012). Mitochondrial pseudogenes in insect DNA barcoding: differing points of view on the same issue. Biota Neotropica 12, 301-308. DOI: 10.1590/S167606032012000300029

Mandefro, W. \& Dagne, K. (2000). Morphological variation of root-knot nematode populations from Ethiopia. Pest Management Journal of Ethiopia 4, 19-28.

Mgonja, D., Temu, G., Mziray, M., Kashando, B., Mwenisongole, A., Masunga, M., Lyantagaye, S. \& Luambano, N. (2019). Morphological and molecular identification of Pratylenchus goodeyi associated with Banana in Tanzania. Tanzania Journal of Science 45, 265-278.

Nakato, V., Mahuku, G. \& Coutinho, T. (2018). Xanthomonas campestris pv. musacearum: a major constraint to banana, plantain and enset production in central and east Africa over the past decade. Molecular Plant Pathology 19, 525-536. DOI: $10.1111 / \mathrm{mpp} .12578$

Peregrine, W. \& Bridge, J. (1992). The lesion nematode Pratylenchus goodeyi an important pest of ensete in Ethiopia. Tropical Pest Management 38, 325-326. DOI: 10.1080/ 09670879209371719

Quimio, A. \& Tesera, M. (1996). Diseases of enset. In: Proceedings from the international workshop on Enset, Addis Ababa (Ethiopia) 1993. IAR - Institute of Agricultural Research.

Sher, S.A. \& Allen, M.W. (1953). Revision of the genus Pratylenchus (Nematoda: Tylenchidae). University of California Publications in Zoology 57, 441-470.

Sikora, R.A., Coyne, D., Hallmann, J. \& Timper, P. (Eds) (2018). Plant parasitic nematodes in subtropical and tropical agriculture, 3rd edition. Wallingford, UK, CAB International.

Simmonds, N.W. (1962). The evolution of the bananas. London, UK, Longmans.

Speijer, P. \& Bosch, C.H. (1996). Susceptibility of Musa cultivars to nematodes in Kagera Region, Tanzania. Fruits 4, 217-222. 
Speijer, P. \& Fogain, R. (1998). Musa and Ensete nematode pest status in selected African countries. In: Frison, E.A., Gold, C.S., Karamura, E.B. \& Sikora, R.A. (Eds). Mobilizing IPM for sustainable banana production in Africa. Proceedings of a workshop on banana IPM. Nelspruit, South Africa, INIBAP, pp. 98-108.

Studholme, D.J., Wicker, E., Abrare, S.M., Aspin, A., Bogdanove, A., Broders, K., Dubrow, Z., Grant, M., Jones, J.B., Karamura, G. et al. (2020). Transfer of Xanthomonas campestris pv. arecae and $X$. campestris pv. musacearum to $X$. vasicola (Vauterin) as $X$. vasicola pv. arecae comb. nov. and $X$. vasicola pv. musacearum comb. nov. and description of $X$. vasicola pv. vasculorum pv. nov. Phytopathology 110 , 1153-1160. DOI: 10.1094/PHYTO-03-19-0098-LE

Swart, A., Bogale, M. \& Tiedt, L. (2000). Description of Aphelenchoides ensete sp. n. (Nematoda: Aphelenchoididae) from Ethiopia. Journal of Nematode Morphology and Systematics 3, 69-76.

Tesera, M. \& Quimio, A. (1994). Research on Enset pathology. In: Proceedings of the 2 nd national horticultural workshop of
Ethiopia, Addis Ababa 1992. IAR - Institute of Agricultural Research.

Waeyenberge, L., Ryss, A., Moens, M., Pinochet, J. \& Vrain, T.C. (2000). Molecular characterisation of 18 Pratylenchus species using rDNA Restriction Fragment Length Polymorphism. Nematology 2, 135-142. DOI: 10.1163/ 156854100509024

Westphal, E. \& Stevels, J.M.C. (1975). Agricultural systems in Ethiopia. Agricultural research reports, volume 826. Wageningen, The Netherlands, Centre for Agricultural Publishing and Documentation.

Wiśniewska, O. \& Kowalewska, K. (2015). Some observations on Malenchus pressulus (Kazachenko, 1975) (Nematoda: Tylenchidae) from Białowieski National Park, Poland. Annales Zoologici 65, 123-130. DOI: 10.3161/00034541ANZ2015. 65.2.001

Zuur, A.F., Ieno, E.N. \& Elphick, C.S. (2010). A protocol for data exploration to avoid common statistical problems. Methods in Ecology and Evolution 1, 3-14. DOI: 10.1111/j. 2041-210X.2009.00001.x 